\title{
Çoklu Deneyimin Sembolik Mekânları: Alışveriş Merkezleri
}

\author{
DOI: $10.26466 / o p u s .471825$
}

\author{
Ömer Aytaç* - Musa Öztürk \\ * Prof. Dr. Fırat Üniv. İnsani ve Sosyal Bilimler Fak. Sosyoloji Böl. Elazığ/Türkiye \\ E-Posta: oaytac75@hotmail.com ORCID: 0000-0002-5435-7107 \\ * Doç. Dr. Ankara Yıldırım Beyazıt Üniv. İnsan ve Toplum Bilimleri Fak. Ankara/Türkiye \\ E-Posta: musaozturk724@gmail.com ORCID: 0000-0001-8438-1821
}

\section{$\ddot{O} z$}

Bu çalışmada modern kent yaşamının merkezinde yer alan alışveriş merkezleri; çoklu deneyimin sembolik mekânları olarak nitelendirilmektedir. Buralar kent sakinlerinin birçok şeyi aynı çatı altında, eşzamanlı olarak deneyimleyebildiği mekânlardır. Bu yönüyle alışveriş merkezleri yalıtılmış ve steril bir sosyal ortam sunmaktadırlar. Bu şekilde kitleleri büyüleyerek daha yoğun olarak kendilerine çekebilmek için birbirinden alabildiğince farklı deneyimleri tek bir çatı altında sunarak işlevselliklerini arttırmaktadırlar. Bu açıdan düşünüldüğünde, alışveriş merkezlerinin pek çok insan için sosyalleşme mekânı olmanın ötesinde başlı başına bir sosyalleşme vasıtasına dönüştükleri gözlenmektedir. Çalışmada alışveriş merkezlerinin sunmuş olduğu bu kurgusal ya da sembolik deneyim; neoliberalizm, kamusallık/kamusal alan, tüketimin manipülasyonu ve kültürel değerlerin metalaşması perspektiflerinden eleştirel bir bakış açısıyla ele alınmaktadır. Araştırma sonucunda alı̧veriş merkezlerinin eğlenme, dinlenme, seyretme/izleme, vakit geçirme, oyun oynama, statü/prestij ve kimlik edinme gibi tatmin vasıtaları sayesinde gündelik yaşamın sıkıcllı̆̆ın, rutinliğini aşmaya hizmet ettiği sonucuna varılmıştır.

Anahtar Kelimeler: Tüketim, Mekân, Alışveriş Merkezi, Tüketimci Kapitalizm

OPUS (c) Uluslararası Toplum Araştırmaları Dergisi-International Journal of Society Researches ISSN:2528-9527 E-ISSN : 2528-9535

http://opusjournal.net 


\title{
Symbolic Spaces of Multiple Experience: Shopping Centers
}

\begin{abstract}
In this article, shopping malls which are on the centre of modern urban life were characterized as symbolic spaces of multiple experiences. In these places urban dwellers can experience a lot of things at the same time and space. By this way shopping malls, provides an isolated and sterilized social environment. They increase their functionality, by providing various experiences which are deeply different from each other under one roof to fascinate and attract the masses. From this point of view it is observed that, for many people, shopping malls had been transformed to a medium of socialization rather than being a space for socialization. In this work, this fictional or symbolic experience provided by shopping malls, were analysed in a critical point of view within the perspectives of neoliberalism, publicity/public space, manipulation of consumption and commodification of cultural values. As a result of research the article concluded that shopping malls serve to escape from the dullness of daily life routines by providing means of satisfaction such as prestige, status, identity formation and areas of spending time for entertainment, playing games, resting, relaxing and watching.
\end{abstract}

Keywords: Consumption, space, shopping center, consumptive capitalism 


\section{Giriş}

Kent mekânları içerisinde alışveriş merkezleri, plazalar, hipermarket ve grosmarketler önemli yer tutmaktadırlar. Hem kentli yurttaşların gündelik yaşamlarında her geçen gün kapladıkları yerin artış göstermesi hem de küresel değişim trendini en iyi örneklemesi açısından alışveriş merkezleri modern toplumda merkezi bir önem taşımaktadır. Pek çok çağdaş sosyolog, alışveriş merkezlerini "büyülü mekânlar" olarak görmektedir. "Tüketim katedralleri”, "alışveriş sarayları”, "alışveriş kasabaları", "shoping malls" vs. de denilen bu mekânlar, gerek tüketimin estetikleşmesini gerekse de müşterilerde, gösterişli, coşkulu, heyecanlı kendini kaptırmışlık türünden karnavaleks duygular yarattıklarından dolayı kentin "büyülü mekânları" olarak nitelendirilmektedirler.

Tüketimci kapitalizmin yükselişiyle birlikte, alışveriş merkezleri, plazalar, marketler, pasajlar, eğlence ile tüketimin iç içe geçtiği "tüketim sarayları" hızla yaygınlaşmaya başlamıştır. Tüketimin esaslı bir yaşam ereği olarak kabul görmesi, tüketim aktivitelerine katılımı arttırdığı gibi, tüketim mekânlarının popülerliğini ve demokratikleşmesini de mümkün kılmıştır. Kapitalizmin gelişmesine koşut olarak modern mağazalar hem tüketim ilişkileri hem de mekânsal olarak büyük bir değişim içine girmişlerdir. Tüketimin modern toplum için anahtar bir kavram haline gelmesi ile tüketimin yoğunlaştığı alışveriş mekânları merkezi bir önem kazanmaya başlamıştır. Bir zamanlar fabrika üretim için ne anlama geliyorsa bugün de modern mağazalar tüketim için o anlama gelir olmuştur.

Alışveriş merkezi, hipermarket, süpermarket gibi tüketim mekânlarını birer "tüketim araçları" olarak isimlendiren Ritzer'e göre, tüketim mekânları da üretim mekânları (araçları) gibi akılcılaştırılmıştır. Ancak bu akılcı taraflarını 1srarla gizleyerek, tüketiciye kendilerini büyülü mekânlar olarak sunmaktadırlar. Tüketim mekânlarının insanların mal ve hizmet ihtiyaçlarının karşılanması ile ilgileri kalmamıştır. Bu mekânlar insanları sürekli olarak çeşitli uyarıcılarla tüketime teşvik etmektedir. $\mathrm{Bu}$ bir dizi büyüleme mekanizmasının devreye sokulmasını gerektirmektedir (Ritzer, 2000). Tüketim bu tür mekânlarda bir ihtiyaç gidermenin ötesinde adeta bir ibadet, dini bir deneyim olarak yaşanmaktadır. Tüketim dinselleştirilmesi, tüketim malları temin edilen bu yerleri 
tapınaklar haline getirerek, tüketim edimini gerçekleştirmek amacıyla "hacca gidilen" yerler, mahaller, mekânlar haline getirmektedir. ${ }^{1}$

Alışveriş merkezleri Batı dünyasında sanayi kapitalizmi, kentleşme ve fordist üretim süreçleri sonunda üretim fazlasını massederek sermaye dolaşımının/birikiminin hızlandırılması için geliştirilen bir tüketim stratejisinin sonucunda geliştirilmiştir. Merkez-çevre ilişkileri bağlamında kapitalizmin merkez ülkelerinde geliştirilen bu tükettirme modeli, 1980 sonrası neo-liberal genişleme dalgasıyla hızla yaygınlaştığı görülmektedir. Günümüzde alışveriş merkezleri pek çok hizmetin aynı çatı altında profesyonel olarak sunulduğu, kentlerin ve kentlilerin vazgeçilmez mekânları haline gelmişlerdir. Alışveriş merkezleriyle ilgili hukukçular, iletişim bilimciler, mühendisler, mimarlar, şehir ve bölge planlamacılar, güzel sanatlar, kamu yönetimi, turizm, sosyologlar, psikologlar, işletmeciler, pazarlamacilar gerek teorik, gerekse de uygulamalı sayısız araştırmalar yapmaktadırlar. Bu kadar çok disiplinin alışveriş merkezleriyle ilgili araştırma yapması aslında bu tür mekânların hayatımızda ne kadar yer ettiğini göstermektedir. Literatüre bakıldığında alışveriş merkezleriyle ilgili toptancı bakış açısının ön plana çıktığı, belli ve sınırlı perspektiften bakan yaklaşımların ağırlıkta olduğu gözden kaçmamaktadır.

Biz de bu çalışmada alışveriş merkezlerini farklı açlardan ele alarak, modernliğin ürettiği yeni yaşam stillerinin en çarpıcı gösterenleri arasında yer alan alışveriş merkezlerine dayalı deneyimlerin sosyolojik arkaplanına ışık tutmaya yönelmekteyiz. Bu bağlamda, alışveriş merkezlerinin neoliberalizmle ilişkisi, kamusallık ardalanı, tüketimcilik kültürü ve gündelik hayatın büyülenmesine dönük etkilerine açıllık getirilmeye çalışılmaktadır.

\section{Neoliberalizm, Kent ve Alışveriş Merkezleri}

Küreselleşmeyi tetikleyen iletişim, ulaşım/ulaştırma ve pazarlama faaliyetlerinin gelişmesi tüketim alanını önemli ölçüde etkilemiştir. Teknolojinin tüketim taleplerini karşılayabilme kapasitesini arttırması

\footnotetext{
${ }^{1}$ Mesela; hacca veya umreye giden birçok Müslümanın vakitlerinin önemli bir bölümünü "Zem Zem Tower"ın altındaki alışveriş merkezinde geçirmeleri orayı adeta yeni ve alternatif bir hac mekânına dönüştürmektedir.
} 
tüketimin genişlemesine ve bir anlamda küreselleşmesine olanak sağlamıştır (Castells, 1997, s. 30). Ödeme imkânlarının kolaylaşması noktasında kaydedilen gelişmeler mal ve hizmetlerin küresel düzeyde dolaşımının hızlanmasını teşvik etmektedir. Mesela; ABD menşeli Visa ve Master Card gibi ödeme araçları dünyada yaygın olarak kullanılmaktadır. Bu tür ödeme araçları yerel olanların da bunlara katılımıyla birlikte dünyanın pek çok bölgesinde her geçen gün daha büyük oranda kabul görmekte ve kullanılmaktadır. Bu, bir yandan küresel tüketimi arttırırken diğer yandan küresel tüketicilerin (turistler de dahil) dolaşımını hızlandırmaktadır (Ritzer, 2011a, s. 252). Ulaşım maliyetlerindeki düşüş yerden ve mekândan kaynaklanan engellerin aşılmasını kolaylaştırdığından kentler arası rekabeti görünür bir şekilde arttırmıştır. Kentler arası rekabetin ve kent girişimciliğinin artması kent mekânlarını her türlü yeni gelişim örüntüsünün serpildiği birbirine benzer yerlere dönüştürmüştür. Artık nereye gidersek gidelim hemen her yerde bilim parklarl, mutenalaştırma, ticaret merkezleri, kültür ve eğlence merkezleri, postmodern donanımlara sahip geniş çapta kapalı alışveriş merkezleri vb. (Harvey, 2012a, s. 423-425) mekânlarla karşılaşmak sıradan bir olgu haline gelmiş durumdadır.

Kapitalizmin mekânsal olarak genişlemesi üretim ilişkilerinin rasyonel bir şekilde örgütlenmesi sonucunda gelişmiştir. Bu ilişkinin mekâna dayalı olarak daha da büyüyebilmesi mekânın üzerinde barındırdığı değişkenlerden bağımsız olarak kontrol edilebilmesine ve soyut bir sistem üzerine oturtulmasına ihtiyaç duymaktadır. Alışveriş merkezleri üzerinden aynı mekân anlayışının her coğrafyada tekrarlanması coğrafyanın sermayenin "istekleri doğrultusunda soyut bir mekân ve zaman anlayışı çerçevesinde yeniden" kurgulanarak dönüştürülmesini içermektedir. Böylece "birbirinden çok farklı coğrafyalar aynı soyut mekân ve zaman anlayışı" etrafında birbirine bağlanarak tek bir ekonomik sistemin parçası haline getirilebilmektedir (Yırtıcı, 2005, s. 59-60). Dünyanın hemen her yerinde benzer mekânların (otel, alışveriş merkezi, havalimanı, vb.) hızla çoğalması Thomas Friedman'ın Dünya Düzdür (2006) tezini güçlendirmektedir. Bazı kentlerde bu tür mekânların olmaması buraların geri kalmışlıkla, kentsel yoksullukla ilişkilendirilmesine neden olduğundan kentlerin ziyaret edilme olasılığını azaltmaktadır. Kentler bunun üstesinden gelebilmek için 
kendilerini sermaye akımlarına göre konumlandırmaya zorlanmaktadırlar.

Neoliberalizmde kentin kaderini kent sakinleri değil sermaye belirlemektedir. Sermayenin kentlileşerek dönüştürücü bir aktör olarak kent mekânlarına saldırması kent mekânlarının sermaye akımlarının hızına göre yeniden kurgulanmasını ve biçimlendirilmesini beraberinde getirmiştir. Dolayısıyla artık modern kentler geleneksel kentler gibi doğal seyri içerisinde genişleyen ve büyüyen "yer/ler" değildir. Kentin kaderi "büyüme makinesi" siyasetinin aktörleri olan ticaret odalarının, yerel/ulusal/uluslararası sermayedarların, sanayici/tüccar lobilerinin, emlak spekülatörlerinin ve şehir planlamacılarının yuvarlak masasında kararlaştırılmaktadır (Harvey, 2012a, s. 415). Bunlar kentin geleceğiyle ilgili kararlar almak için sık sık bir araya gelirlerken sermaye dışındaki aktörler (kent yoksulları, işçiler, vb.) mekânsal olarak dışlandıkları gibi karar alma süreçlerine dahil edilmeyerek temsil hakları sermaye tarafından gasp edilmektedir. Müteahhitlerin bilinçli olarak kentlerin içine yerleştirmiş oldukları iktidar peyzajları ve sahne dekorları sayesinde kentler görsel tüketimin düşsel peyzajına dönüşmüş durumdadırlar (Urry, 1999, s. 41).

Bu bağlamda alışveriş merkezleri sermaye için önemli yatırım ve istihdam mekânlarıdırlar. Küçük ölçekli ortalama bir fabrikada çalışan iş̧̧i sayısı kadar eleman bazı alışveriş merkezlerinin tek bir mağazasında istihdam edilebilmektedir. Mimari açıdan bu tür mekânlarda sermayenin devir hızı son derece yüksek olduğundan neoliberalizm postmodern mimarlık ve mekân pratikleri üzerinden sermayenin devir hızını arttırmak için bu tür mekânların üretimini teşvik etmektedir. Sermayenin mekâna bu denli saldırması başta Castells, Harvey, Lefebvre ve Urry olmak üzere pek çok düşünürün kent mekânları hakkında eleştirel bir söylem geliştirmelerine zemin hazırlamıştır. Bugün artık kent mekanları geçmişte olduğu gibi sorgulanmadan, eleştirel bir süzgeçten geçirilmeden kullanılan veya içerisinde yaşanılan nötr yerler değildirler. Postyapısalcıların iktidarı merkeze alarak yapmış oldukları çözümlemelerden mekân da nasibini almıştır. Mekânın bir kurgu olduğu ve iktidar ilişkileri içerdiği yönündeki bakış açısı hızla yükselmektedir.

Lefebvre'ye (2016, s. 103-104) göre "mekândaki nesneler sadece şey değil aynı zamanda ilişkidirler." Mekân üzerindeki mübadele ağları, 
hammadde ve enerji akışları bir yandan mekânı şekillendirirken diğer yandan mekân tarafından belirlenmektedirler. Dolayısıyla mekânı üretici güçlerden, teknikten, bilgiden, toplumsal işbölümünden, doğadan ve devletten ayrı (Lefebvre, 2016, s. 111) düşünemeyiz. John Urry de Mekânları Tüketmek (1999) adlı kitabının giriş kısmında "Yeni Tüketimde Zaman ve Mekân" başlığı altında mekânın sosyal yönüne dikkat çekmektedir. "Yerin anlaşılması, kuramsal çaba olmaksızın gerçekleşemez. Yere ait toplumsal ilişkiler ve yer'in tüketilmesi gibi görünürde yalın olanı bilmek gelişkin bir toplumsal kuramlaştırma gerektirmektedir. Daha doğrusu neredeyse tüm büyük toplumsal ve kültürel kurumlar yer'in bir biçimde tanımlanmasına dayanırlar" (1999, s. 11-12). Lefebvre ve Urry mekânın iktidar ilişkileri içeren simge ve sembollerle dolu olduğuna ve ideolojik olarak kurgulandığına vurguda bulunurlar.

Harvey (2012a, s. 419-420) ise neolibaralizm baskısı altındaki modern kentlerde tüketicilerin parasını çekmek için yapılan yatırımların paradoksal bir şekilde arttığına dikkatimizi çekmektedir. Mesela; "mutenalaşma, kültürel yenilenme ve kentsel ortamın fiziksel yenilenmesi (postmodern mimari tarzlara ve kent tasarımına dönüşü de içerecek bir şekilde), tüketici çekim merkezleri (stadyumlar, alışveriş merkezleri, marinalar, egzotik yemek yerleri) ve eğlence (geçici ya da sürekli olarak kentsel eğlenceler düzenlemesi) kentsel yenilenmeye yönelik stratejilerin sık rastlanır yüzleri oldular." Sosyolojik açıdan mekân ve özellikle de kent mekânlarl; üzerinde yaşanılan yer olmanın ötesinde toplumsal/"politik aidiyetlere, farklı yaşam deneyimlerine, kimliksel ve kültürel çoğulculuğa, yeni bakış ve düşünsel formlara karşılık gelmektedirler" (Aytaç, 2017). Bu anlamda postmodern bir mimari tarzda inşa edilen alışveriş merkezlerinin çağdaş insanın zihin yapısının silüetini yansıttığı söylenebilir.

Bu bağlamda Marc Auge, alışveriş merkezlerinin zaman ve mekân mefhumlarını da yapibozuma uğrattığı kanaatindedir. Ona göre, alışveriş merkezleri artık belirli bir mekâna ve zamana bağlı değil, buralarda, sürekli bir "şimdiki zaman" yaşanmaktadır. Bu tür alışveriş merkezlerinin kökleri, yer'e ya da belirli bir bölgesel coğrafyaya bağlı değil, pazarlama, halkla ilişkiler ve görüntü idareciliğindedir. Buralarda bir "uzam" fazlalığı söz konusudur. İnsan aynı anda hem Teksas'ta hem de Tokyo ya da Kaliforniya'dadır. Kredileri yetiştiği sürece insanlar 
içeride kimlik kaybı ve rol yapma zevkini tümüyle bireysel bir şekilde tadabilmektedirler (bkz. Durakbaşa ve Cindoğlu, 2000, s. 94). Auge, aynı zamanda, alışveriş merkezlerinde "mekân" imgesinin "metin" tarafindan tümüyle istila edildiğini de belirtmektedir. Ona göre hipermarketler; “(...) müşterinin sessiz bir şekilde dolaştığı, fiyat etiketlerine baktı̆̆ tartı sonucuyla birlikte fiyatı da bildiren bir makinede sebze ve meyvelerini tarttığı, sessiz ya da fazla geveze olmayan bir kasa görevlisine kredi kartını uzattığı, her malın kod okuyucu makineden geçerek toplam fiyatın hesaplandığı ve tüm bu işlemlerin önceden tanımlı bir metin üstünden yapıldığı mekânlardır" (Auge, 1992; Yırtıcı, 2005, s. 81 ).

Sassen, mekânsal olarak desantralize olmuş/dağınıklaşmış global ekonominin, yerel olarak konumlanmış ve bütünleşmiş organizasyonlara ihtiyaç duyduğunu ve bunun global kent çalışmalarının hareket noktasını oluşturduğunu belirtmektedir (Akt. Topal, 2003, s. 48). Bu çalışma bağlamında alışveriş merkezlerinin bunun somut göstergesi olduğunu söyleyebiliriz. Dünyanın pek çok yerinde üretilen malların (filmler, meyveler, elektronik eşyalar, giysiler, vb.) küçücük mekân(lar)da tüketicilerin hizmetine sunulması Sassen'in yaklaşımını doğrular mahiyettedir. Gruen ve Smith (1960) alışveriş merkezlerinin küçük birer kent olarak ele alınması gerektiğini ileri sürmektedirler. "Shopping Towns USA" kitabının giriş yazısında bunu şöyle açılamaktadırlar: "Alışveriş merkezleri farklı yapılanmaların bir araya geldiği komplekslerdir. Bu yapıları bir arada tutan bir ruhun/düşüncenin olması dolayısıyla, bu yapıların tasarımında çevreyi de ele alan bir planlama anlayışı gerekmektedir. Bu gereklilik, ancak alışveriş merkezlerinin günümüzde insanların çeşitli ihtiyaç ve aktivitelerini karşılayan kentsel organizmaların karakteristiğine sahip olabilmeleri kaydıyla mümkündür. Bu da bize aslında "alışveriş kasabaları" tasarımının haklılığını göstermektedir" (akt. Vural ve Yücel, 2006, s. 101). Alışveriş merkezleri içinde barındırdıkları sun'i ağaçlar, şelaleli havuzlar, banklar, oyun alanları, cafeler, sinemalar, ATM'ler ve belli bir sistematiğe göre çarşı mantığına göre konumlandırılmış mağazalar ile adeta küçük bir kasabayı andırmaktadırlar. Bunun da ötesinde barındırmış olduğu ürün çeşitliliğ̈i, marka/mağaza sayısı, çalışan sayısı, günlük/haftalık/aylık/yıllık ziyaretçi sirkülasyonu, ciro miktarı vb. açılardan pek çok kasabadan ve hatta ilçeden daha canlıdırlar. 
Alışveriş merkezlerinin çekici olmasının (içerisinde barındırmış oldukları mal ve hizmet çeşitliliğinin yanı sıra) bir diğer nedeni de öngörülebilir olmasıdır. Alışveriş merkezleri insanlara kent sokaklarının insanı görece rahatsız ve tedirgin eden eylemlerinden uzak, steril bir ortam sunmaktadırlar. Kötü hava şartlarından, suç eylemlerinden görece uzakta, kapalı, korunaklı steril bir yaya ortamı sunması alışveriş merkezlerinin tercih edilme olasılığını arttırmaktadır (Ritzer, 2011b, s. 146-147). Kuşkusuz tüm bunlar aynı zamanda alışveriş merkezlerini canlı ve yoğun bir ilginin adresi haline getirmektedir.

\section{Kent, Kamusallık ve AVM'ler}

Modern kentlerde alışveriş yapmak, sadece satın almayı değil, aynı zamanda eğlenceyi, görmeyi, dolaşmayı, yeme/içmeyi de içeren çoklu bir deneyimi içerir. Buralar aynı zamanda bireysel, grupsal, kolektif deneyimlere açıklık göstermekte, birlikte-toplu halde yapılan aktivitelere ev sahipliği yapmaktadırlar. Alı̧̧veriş merkezleri, ürün ve hizmetleri tüketmenin adresi olmanın ötesinde ortak deneyimler, alış/satışı içeren simgesel ve hayali ilişkilere de karşıllk gelmektedirler. Durakbaşa ve Cindoğlu'nun (2000, s. 93) da ifade ettikleri gibi, bu mekânlar kolektif hayal gücü için birer mekân olarak gözüküyorlar. Zira; “...ortamın zengin, modern, lüks havası kente ait olma hissini pekiştirir. Bu alışveriş merkezlerine gittiğinizde, kendinizi bütün bu ürünlere ve mekânlara erişimi olan daha üst sosyo-ekonomik sınıflara aitmiş gibi hissedersiniz. Bir şeyler satın almanız beklenen küçük dükkân deneyiminin tersine, burada sadece dolaşabilir ve yine de dışarıda kalmadığınızı hissedebilirsiniz. Bu mekânlar her tür sosyo-ekonomik gruptan insana açıtır. Alışveriş merkezi, aynı zamanda ailenin eğlence mekânı, gençlerin takılabilecekleri bir buluşma noktasıdır. Birçok ebeveyn alışveriş merkezinin çocukları için güvenli bir yer olduğuna inanır, çünkü en azından onların nerede olduklarını bilirler. Burası gençlerin karşı cinsle kaynaşmayı öğrenebileceği ve toplumsal alanda kendini gösterebileceği kapalı ve denetimli bir yerdir."

Alışveriş merkezleri müşteriler için güvenli bir alan sunmaktadırlar. Giriş-çıkışlar sürekli kontrol edildiğinden alışveriş merkezlerinde kapkaç, suç vb. eylemlere pek rastlanmaz. Suç oranlarının yüksek olduğu 
bazı kentlerde aileler çocuklarını sosyalleşmek için alışveriş merkezlerine getirirler. Buralar alışveriş ve eğlencenin yanında spor amaçlı da kullanıldığından modern kentlerde popülerleşmiştir. Özellikle suç oranlarının yüksek olduğu kentlerde yaşayanlar için güvenli bir liman işlevi görürler. Hem oyuncakların niteliği hem de gözlemci personelin bulunması "nedeniyle eğlence merkezlerinde çocukların yaralanmasına normal oyun parklarına oranla daha az rastlanır" (Ritzer, 2011b, s. 147). Ticari özelliklerinin yanı sıra çekiciliklerini arttırmak için bünyelerine eklemiş oldukları diğer faaliyetlerin yanı sıra sunmuş oldukları fiziksel ve sosyal olanaklar modern kentin kaotik ortamından kaçmak isteyen insanlar için buraları birer çekim merkezi haline getirmektedir.

Güvenlik noktasından geçtikten sonra kendimizi birden geniş atriumlu, yapay bitkili, yerleri cilalı, vb. bir mekânda bulmamız biz ziyaretçilerde hayret uyandırmak için kasıtlı olarak tasarlanmıştır. Fakat aynı zamanda her türlü aşırı coşku ifade eden davranışlardan (örneğin yüksek sesle gülmek, bağırmak, koşmak vb.) uzak durmanın gereğinin de farkındayızdır. Hepimiz son derece vakur şekilde bu yeni yaşam pratiğinin içinde yerlerimizi alırız. Buranın kapısından adımımızı içeriye attıktan sonra içerideki herkes birbirine eşittir. Statü farkı gözetmeksizin satış görevlileri hepimizi standart sözcükler ve mimiklerle karşılar. Buralardaki "banklar, havuzlar, atriuma bakan geniş teraslar herkesin özgürce oturup, dinlenmesi ve etrafı seyretmesi için tasarlanmıştır" (Vural ve Yücel, 2006, s. 104-105). Kisaca ifade etmek gerekirse yere ilişkin postmodern peyzajların tamamı tüketimi simüle etmeyi amaçlamaktadır.

Dev bir iletişim ve bilgisayar şebekesi ile bağlantılı temsillerin kökeninde günümüzün çokuluslu kapitalizminin çarpıtılmış figürü yatmaktadır. Çağdaş toplum sadece teknoloji tarafından değil, teknolojiyi de kontrol eden zihinlerimizin ve düş gücümüzün kavrayabilmesi neredeyse imkânsız olan bir güç ve kontrol şebekesi tarafından kontrol edilmektedir. Sermayenin merkezsizleşmesinin beraberinde getirmiş olduğu bu yeni global durum bugün en iyi biçimde çağdaş eğlence üzerinden kendisini göstermektedir (Jameson, 2011, s. 79). Adorno daha 1940 'l y yllarda medyanın tektipleştirici ve homojenize edici etkisini fark ederek bunun kültürü nasıl şekillendirdiğine dikkatimizi çekmişti. Film, radyo, dergi vb. iletişim araçları bir sistem oluşturacak şekilde birbirine 
entegre edilerek her şeye benzerlik bulaştırılmıştır. Ve bu öylesine birleştirici ve uzlaştırıcı bir güce sahiptir ki "siyasal karşıtlıkların estetik ifadeleri bile bu çelikten ritme hevesle uymakta" birleşmektedirler (2011, s. 47).

Toplumsal süreklilik için elzem olan toplumsal birlik, beraberlik ve dayanışma ruhu, gerçekte, kültürel, dini vb. değerler etrafında insanların kümelenmesiyle oluşur. Bu değerler çoğu zaman sermaye birikiminin ve piyasa değerlendirmelerinin arı işleyişine, promosyoncuların ve imaj yaratıcıların bütün çabalarına rağmen boyun eğmeyen, dirençli değerlerdir. Fakat son yıllarda değerlerden kaynaklanan direnci kırarak aradaki açığı kapatabilmek adına "imagineering (imaj mühendisliği) denen koskoca bir danışmanlık alanı icat edilmiştir (Harvey, 2012b, s. 200-201). Reklam endüstrisi vasitasıyla tamamen soyut göstergeler etrafında yeni bir birliktelik inşa edilmektedir. Marka ve imajlar üzerinden insanlar yeni kimlikler oluşturarak kendilerini diğerlerinden farklılaştırmaktadırlar. $\mathrm{Bu}$ anlamda alışveriş merkezleri basit anlamda sadece tüketim mekânları değildirler. Bunun ötesinde sınıf, statü, prestij, itibar, ırk, etnisite, toplumsal cinsiyet vb. üzerinden toplumsal hiyerarşilerin yeniden kurulup bozulduğu, rol ve statülerin yeniden dağıtıldığı yerlerdirler. Bazı insanlar sınıfsal "konumlarını yansıtabilmek ya da öykündükleri statülere yükselmek için ödünç" semboller/göstergeler toplamak için buralarda toplanmaya ve görünmeye (Aytaç, 2017, s. 254) büyük önem verirler. İnsanlar bazı mekânlarda görünmenin, belli markalardan giyinmenin bir statü göstergesi olduğunu bilirler.

Fiziksel ortamın tasarımı üzerinden sosyal ilişkilere yön verilirken aynı zamanda mekan içerisinde hazzı arttırmak için "alışveriş," boş zaman ve rekreasyon faaliyetleriyle birlikte sunulmaktadır. "Günümüz kentlerinin simgesi haline gelen bu mekânlar tasarımcı dokunuşlarıyla önemli birer 'keyif ve haz' mekânı olarak karşımıza" çıkmaktadırlar (Goss 1993). Alışveriş merkezleri küresel kapitalizmin birçok fantastik imgesinin tüketilmesini sağlayacak şekilde kurgulanmıştır. Bir yandan mekân tasarımı üzerinden farklı kullanıcılar için güvenli bir atmosfer oluşturulurken diğer yandan da mağaza ve dükkân tasarımlarında mimari açıdan gösterişli malzeme ve karmaşık dekorlar kullanılarak konfor seviyesi maksimize edilmeye çalışılmaktadır (Müğan Akıncı, 
2013, s. 88). Bu yönüyle mekân herkesi kendine davet ederek kimseyi dışarıda bırakmamaya özen gösterir gibi görünür ama fiyat etiketleri üzerinden araya sembolik bir mesafe konulur. Yeterli düzeyde satın alma gücüne sahip olmayanlar ya da yoksullar ürünlerin üzerine iliştirilmiş olan fiyat etiketleri üzerinden kibarca dışlanırlar. Buna rağmen insanlar buraları ziyaret etmekten de uzak durmazlar. Burada diğer insanlarla etkileşim kurmak yerine mekânın bizzat kendisiyle ve mekânın sunduğu mal ve hizmetlerle etkileşime girerler. Çünkü cazip olan ne içerideki insanlar ne de mal ve hizmetlerdir. Çoğunlukla cazip olan bizzat mekânın kendisidir. Tüketici ister bir fast food retoranı, isterse de bir alışveriş merkezi, yolcu gemisi, eğlence parkı ya da kumarhane olsun ortamla etkileşim (Ritzer, 2000, s. 225-226) kurarak mekânı tüketmektedirler.

Aslında alışveriş merkezlerinin geleneksel uygarlıkların din/dinî merkezleriyle pek çok ortak yanları vardır. Bu tür dini merkezler gibi alışveriş merkezleri de insanların festival ve şölenlere katılma ihtiyaçlarına cevap vermenin yanı sıra birbirleriyle ve doğayla (ağaçlar, bitkiler, çiçekler, vb.) ilişki kurmalarına da olanak sağlamaktadır. Mimari açıdan bakıldığında alışveriş merkezleri geleneksel olarak tapınakların sağladığ türde bir merkezlilik sağlamak için benzer bir denge, simetri ve düzene sahip olacak şekilde inşa edilmektedirler. Mesela; atriumlar genellikle su ve bitkiler aracılığıyla doğayla bağlantı kurmamızı sağlarlar. İnsanlara özel cemaat hizmetleri sunmanın yanı sıra bir topluluğa dahil olma duygusu da aşılamaktadırlar (Ritzer, 2000, s. 26-27). Fakat yakından incelendiğinde alışveriş merkezlerinin sunduğu toplumsallığın genellikle bireylerden ziyade gruplara bağlı olduğu görülmektedir. Mesela; çalışmayan kadınlar alışveriş merkezlerinde buluşup arkadaşlarıyla alışveriş yapmakta, yaşlılar yoğunluğun az olduğu sabah saatlerinde buralarda egzersiz yapmaktadırlar. Buralar aynı zamanda arkadaşlarıyla buluşmak isteyenler için yeni sosyalleşme zemini sunmaktadırlar (Zukin, 1998, s. 830).

Alışveriş merkezleri toplumsal cinsiyet politikalarını da yeniden örgütlemektedir. Kadınların bu mekânlarda daha fazla gözüküyor olmaları, onların tüketimci politikaların kontrolüne girmeye daha yatkın olmalarının dışında, alışveriş süreçlerinin büsbütün kapitalist iktidarın eline geçmiş olmasıyla da yakından ilişkilidir. Alışveriş merkezi; “ (...) 
bir bakıma, kişinin mucizevî şekilde sosyal kimliğinden sıyrılıp evrensel bir kimliğe bürünebileceği bir mekân. Kadın müşteriler, ürünlerin kalitesi ve fiyatı hakkında elde ettikleri bilgi sayesinde çoğunlukla kamuya açık alanlarda duydukları güvensizlik hissini üstlerinden atabiliyorlar. Kadınlar, genellikle vitrin bakmak için de zaman harcıyorlar, zira alışveriş merkezinde dolaşırken sahnede oldukların hissediyorlar. Alışveriş merkezi, cemiyet-toplum aracılığıyla gerçekleşen bir edimden ziyade bireysel memnuniyet yoluyla kadınların kapitalist topluma entegrasyonunu sağliyor" (Durakbaşa ve Cindoğlu, 2004, s. 94).

Kostof'un (1992) ifadesiyle söyleyecek olursak "kamusal aktivite kent meydanları, parklar sokaklardan alışveriş yapılarının klimatize edilmiş ortamlarına doğru bir dönüşüm geçirmiştir" (akt. Vural ve Yücel, 2006, s. 97). Kamusal aktivite toplumun içerisinden çekip alınarak son derece steril bir mekanın içine yeniden üretilme yoluna gidilmiştir. Bir başka ifadeyle "alışveriş merkezleri, kimi zaman geçmişe öykünen "kitsch", kimi zaman ise uzay istasyonunu andıran "hightech" iç mekân" kurgusuyla çağımızın yeni kamusal mekânlarını oluştururlar. Burada cereyan eden kamusal ilişkiler de, tıpkı alışveriş merkezinde kurgulanan yapay dünyaya benzer bir şekilde spontaneliğini yitirmiştir. İklimlendirmesinden "güvenlik kontrolüne kadar fiziksel ortama dair her şeyin düzenlenmiş olduğu alışveriş merkezlerinde kamusal ilişkiler de" düzenlenir olmuştur." AVM "içindeki satış görevlilerinden güvenlik personeline kadar pek çok çalışanın müşterilerle kuracağı ilişkiler, diyaloglar bu düzlemde içinde yer almaktadır. Baudrillard'ın dediği gibi, günümüz "kamusal mekânları olan alışveriş merkezlerinde kamusal ilişki de kendiliğindenliğini kaybetmiştir" (Vural ve Yücel, 2006, s. 105). Dolayısıyla alışveriş merkezlerinin hayatımıza girmesiyle bir anlamda kamusal ilişki formları ve kamusal mekân anlayışı da değişmiştir.

Modern kentlerde yeni sosyalleşme, buluşma, görüşme mekânları olarak alışveriş merkezleri ön plana çıkmıştır. Alışveriş merkezleri bir

\footnotetext{
${ }^{2}$ Pek çok gözlemciye göre, kamu alanları olarak ifade edilen şey, aslında, özelleşmiş kamusal mekânlardır. Örneğin, farklı bir hikâyesi bulunan shopping malls, son elli yılı aşkındır şehrin çekici ve albenili yeni merkezini oluşturmaktadır (Rybczynski, 1993). Shopping malls, şirket plazaları, pasajlar, galeriler ve kamusal mekanlar bir illüzyon yaratan temalı mekanları oluştururlar. Özel ve kamusal arasında yaratılan bu farklılıklar, Mircae Eliade'nın kutsal ve profan mekânlar nosyonunun aksine ya da Mary Douglas'ın Saflık ve Tehlike (2017) tezinden ayrı olarak, günlük hayatın belirsizliği ve riskini de taşırlar (Banerjee, 2001: 9).
} 
yönüyle kamusallığı çağrıştırsalar da giriş-çıkışların denetim altında tutulması, ürünlere dokunulmasını engelleyen bariyerlerin (etiketlerin) olması, dükkân/mağaza önlerine rastgele oturulamaması, gazete okunamaması, miting, gösteri veya protesto hareketleri düzenlenememesi, kamusal meseleleri tartışacak kahvehane ve benzeri olanaklardan yoksun olması vb. nedenlerden ötürü gerçek anlamda kamusal bir mekân olmaktan uzaktırlar (Vural ve Yücel, 2006, s. 97). Bir zamanlar kentin siyasal, sosyal ve ekonomik yaşamını bir parçası olan ve kendiliğinden gelişen kamusal aktiviteler yerini eğlenceye bırakması kamusal aktivitenin anlamını değiştirdiğinden kamusal yaşamın geçtiğ mekânlar konusundaki anlayışları da dönüşüme uğratmıştır.

\section{Tüketimin Kutsanarak Tüketicinin Manipülasyonu}

Günümüz dünyasında tüketim, tüketicilere bırakılamayacak kadar önemli hale gelmiştir. Tüketicilerin kendi kendilerine karar vermelerine izin verilmez. Özellikle sanayi/endüstri ve hükümetler başta olmak üzere büyük güçler tüketicilerin olabildiğince kontrol edilebilmesi için yoğun çaba sarf etmektedirler (Ritzer, 2012, s. 4). Tüketicilerin karar almalarına yardımcı olmak için 20. Yüzyılın ilk çeyreğinde reklam endüstrisi devreye sokulmuştur. Reklam endüstrisi sayesinde ayrımlar zihinlere kazınarak izleyicilere seri/ler halinde nitelik hiyerarşisi ulaştırılmaktadır. Herkes, önceden bir takım göstergelere göre belirlenerek "belli başlı tüketici tipleri için üretilmiş kitlesel üretim" kategorilerinden kendine denk düşenine yönlendirilmektedirler (Adorno, 2011, s. 51). Teknolojik ve finansal okur-yazarlığın artmasının bir sonucu olarak insanlar artık dünyanın neresinde olurlarsa olsunlar tüketim sürecinde ne yapmaları gerektiğini gayet iyi bilmektedirler. Mesela; bir alışveriş merkezinde yollarını nasıl bulacaklarını, kredi kartını nasıl kullanacaklarını ya da internet üzerinden bir malı nasıl sipariş edeceklerini (Ritzer, 2011a, s. 254) hemen hemen bilmeyen yoktur. Bilmeyenler de en kısa zamanda bunları öğreneceklerdir. Mal ve hizmetlerin küresel dolaşımı, kredi kartları ve diğer kredi imkânlarıyla bunların teminini mümkün hale getirdiğinden ihtiyaç baskısından ötürü süreç içerisinde bunların öğrenilmesi kaçınılmaz hale gelmektedir. 
Tüketim baskısı insanları ihtiyaçlarından daha fazlasını almaya ve ödeyebileceklerinden daha fazla borca girmelerine yol açmaktadır. Ritzer bu durumu "hipertüketim" ve "hiperborçlanma" olarak kavramsallaştırmaktadır (2012, s. 11). Tüketim ve borçlanma bakımından çok tutucu olan pek çok ülkenin son zamanlarda alelacele bu yöne saptığı görülmektedir. Uzun yıllar Batı blokunun dişında yer almış olan Çin ve Hindistan gibi büyük ve kalabalık ülkeler bile bu istikamete yönelmiş görünmektedir. Aşırı- tüketim, aşırı-borçlanma ve bunlarla bağlantılı sorunlar küresel bir olgu haline gelmektedir (Ritzer, 2011a, s. 252-253). Kredi ve kredi kartları üzerinden borçlandırma mekanizması o kadar profesyonel bir şekilde kurgulanmıştır ki alışveriş ve harcama esnasında hiçbir şey fark etmeyiz. Aslında büyüleyicilik de tam bu noktada devreye girmektedir. Glasgowlu bir basınla ilişkiler sorumlusunun ifadesiyle söyleyecek olursak; "borç bulmak ve kredi almak öylesine kolay ki dükkânlardaki her şeyin size adeta hediye olarak verildiğini sanırsınız... Hakikaten oturup da faturalarınızı inceleyene kadar harcadıklarınızın sahici paralar olduğunu pek kavrayamazsınız; bunu anladığınızda da şok geçirirsiniz" (Ritzer, 2011a, s. 253). Bazı zincir mağazalar taksitle satışı yasaklanan ürünlerin (mesela, cep telefonu) satışını kolaylaştırmak için müşterileri anlaşmalı oldukları bankalara yönlendirmektedirler. Müşteriler ilgili bankalardan kredi kullanarak ürün bedelini peşin olarak öderlerken kredi taksiti ödemeye de devam etmektedirler.

Bir zamanlar insanların çoğu vakitlerinin önemli bir bölümünü üretim için harcarken günümüzde bu trendin tamamen tersine döndüğü görülmektedir. Artık insanlar vakitlerinin önemli bir bölümünü değil üretime sadece tüketime bile harcamamakta aynı zamanda kendilerini giderek tükettikleri "şeyler"le tanımlamaya yönelmektedirler (Ritzer, 2011a, s. 254). Arz edilen ürünlerin artması moda ve reklam endüstrisi sayesinde onları edinmeye eğilimli tüketicilerin sayısının da artmasını beraberinde getirmektedir. Ürün kitleselleştikçe enderliği azalmakta ve ayırt edici özelliği kaybolmaktadır (Bourdieu, 2016, s. 201). Moda yaygınlaşarak kitleselleştiği ve anonimleştiği ölçüde moda olma özelliğini kaybettiğinden reklam ve moda endüstrisi öncülüğünde yeni tüketim alanları açılarak piyasa sistematik olarak genişletilmektedir. Yüksek kültürün tüketim alışkanlıklarının alt sınıflar tarafından taklit 
edilmesiyle tüketim talebi diri ve canlı tutulmaktadır. Tüketim mallarına olan talebin bu denli artmış olması, insanları bu mallara sahip olabilmek için uzun saatler çalışmaya zorlamaktadır. "Tüketime yoğunlaşma birçok insanın daha az mal ve hizmet alma karşılığında daha az çalışma ve daha çok boş zaman seçeneğinden vazgeçmesi anlamına gelmektedir" (Ritzer, 2000, s. 62).

Postmodernizmle birlikte sınıf ilişkileri eski belirleyiciliğini kaybetmekte, sınıftan doğan boşluk tüketim tarafından doldurulmaktadır.

Tüketimin yaygınlaşması hayat tarzlarını ve ideolojileri birbirine yaklaştırdığından geleneksel ayırım çizgileri eski koyuluklarını kaybetmektedir. Baudrillard bu durumu "farklılıkların giderek keskinleştiği bir toplumsal hiyerarşi oluşturmak yerine yalnızca belli sınıfları belli göstergeler ve ilişkilere mahkûm edip, belli bir toplumsal sistemin ayrılmaz parçaları haline gelmelerini sağlayan bir ayrımlama, bir ayrıcalıklı kılma görevinin nasıl yerine getirildiğinden" (2009, s. 40) bahsetmek suretiyle betimlemektedir. Aslında "öznenin asıl amacı tüketmek değildir. Özneyi tüketime iten şey, bir anlam verme sistemine benzeyen ve farklılık yaratabilmek, anlamlar yüklemek amacıyla bir kod ve değişik statülere özgü değerler üreten toplumsal yaşamdır. Mallara ve bireysel gereksinimlere akılcı bir yöntemle sonradan uygun işlevler yüklenmesi temel yapısal mekanizmaların bilinçaltına itilmesine yol açmaktadır" (Baudrillard, 2009, s. 74). Çünkü mal/nesne artık sadece/tek başına bir mal değildir. $O$; çağrıştırdığı imaj, ilettiği mesaj ve üzerinde taşıdığı göstergelerle kimliğimizi ve aidiyetlerimizi özetlemekte ve bizim kim olduğumuzu anlatmaktadır.

Benzer şekilde Debord da, tüketimin artık bir tür gösteriye dönüştüğünden söz eder. Asıl belirleyici bir takım toplumsal kodlar ve sembollerdir. Kullanım değeri nesnenin görüntüsü ve toplumsal anlamının gerisinde kalmaktadır. Tüketim mekânları ise, tüketimin gösteriye dönüşmesine yardımcı olmaktadırlar. Her tüketim mekânı aynı zamanda bir simülasyon olduğundan insanların nesnelerle olan ilişkilerini birtakım görüntüler üstünden kurmalarını sağlamaktadırlar. Moda tam da bu noktada devreye girmektedir. İnsanlar nesnelerle toplumsal yönlendirmeye bağlı olarak bir dizi ilişki kurarlarken tüketimin bildik anlamının dışına çıkmaktadırlar. Böylece tüketim olduğundan farklı bir anlam kazanarak büyülü ve mistik bir imgeye dönüşmektedir. Ritzer'in 
de ifade ettiği gibi, tüm bu büyüleme mekanizmalarına karşın tüketim mekânları aşırı derecede rasyonalize olmuşlardır. Başarılarının temelinde verimlilik, hesaplanabilirlik, öngörülebilirlik ve insansız teknolojilere dayalı şekilde, tüketici, işçi ve yöneticileri denetleyerek yönlendirmeleri yatmaktadır (Ritzer, 1996; Yırtıc1, 2005, s. 109).

Modern "şehir yaşamı, bir tarza sahip olma bilincine dayalı tüketimci eğilimleri provake etmektedir. Diğer bir ifadeyle, hem belli bir gruba has belirleyici özellikleri hem de bireysel seçim/tercihleri yansitabilecek bir alan içinde tüketimci eğilimleri pekiştirir. Şehirdeki birey daha çok bir kimlik duygusu yaratabilmek, kim olarak algılanmayı arzu ettiğini" (Chaney, 1997, s. 27) belirtebilmek maksadıyla tüketir. Bireyin kendisini diğerlerinden ayırt etmek için kullandığı giyim kuşam tarzının diğer bireyler tarafından da anlaşılıp yorumlanabilmesi gerekir. Bu da bireyin kendisini ancak diğerleriyle bazı ortak kültürel sembolleri paylaşabildiği ölçüde farklı kılabileceğini gösterir (Chaney, 1997, s. 27). Dolayısıyla tıpk1 ürünler gibi beğeniler de imal ve inşa edilmektedir.

Bourdieu, efektif olarak gerçekleşen beğenilerin arz olunan malların durumuna göre değiştiğini belirtmektedir. Mal(lar) sistemindeki her değişiklik beğeni sisteminde karşılığını bularak beğenilerin değişmesine yol açmaktadır (2017, s. 340). Modern toplumda hemen her tür beğeni reklam ve moda endüstrisi tarafından tüketicilerin eğitilmesi sonucu oluşturulmaktadır. Adorno, her şeyin bizzat üretimin şematizmi tarafından sınıflandırıldığını ve tüketiciye sınıflandırabileceği hiçbir şey bırakılmadığını belirtir. Tüketicilerin yapmaları gereken tek şey kendilerini (boş zamanlarında bile) üretimin birliğine uydurmaktır (2011, s. 53). Reklamlar herkese açık, kamusal ve demokratikmiş gibi görünseler de aslında burada çok güçlü bir yanılsama ve manipülasyon vardır. Adorno'nun ifadesiyle söyleyecek olursak "reklamlar, tüketicileri büyük tröstlere zincirleyen bağları daha da güçlendirir. Başta radyolar olmak üzere reklam ajanslarının talep ettiği fahiş fiyatları sürekli ödeyebilenler, (yani ancak işin içinde) ya da bankaların ve endüstri sermayesinin kararıyla buna uygun bulunanlar, satıcı kimliğiyle sözde pazara ayak basabilirler. Sonunda yine tekellerin cebine dönen reklam giderleri, istenmeyen marjinalleri zorlu bir rekabet savaşında yok etmeyi gereksiz kılar. Reklam giderleri söz sahibi olanların arasına dışarıdan kimsenin girmemesini güvence altına alır. Bu açıdan reklam totaliter devletlerde 
hangi işletmelerin açılıp hangilerinin işletilmesine devam edeceğine karar veren ekonomik kurullara benzer" (2011, s. 101). Bu bize alışveriş merkezlerinde neden hep belirli marka ve mağazaların yer aldığının perde arkasını aydınlatmaktadır. Tüketiciler oraya tüketici rollerini oynamak üzere geldiklerinden markasız ürünlere itibar etmemektedirler.

Modern toplumda tüketiciler hemen her konuda önlerine serilen alabildiğine çok sayıda ürün arasından uygun olanlardan birini seçmeye zorlanmaktadırlar. Tüketiciler karşılaştıkları tüm ürünler ve markalar hakkında önceden fikir sahibi olduklarından markalar etrafında oluşturulan imaj üzerinden tüketicilerin tercihleri yönlendirilir. Ürünler her ne kadar fabrikalarda üretilse de markalar tüketicilerin zihinlerinde oluş(turul)maktadır. Firmaların rekabet yeri pazar alanı değil tüketicilerin zihinleridir. Firmalar ürün konumlandırma stratejileri sayesinde tüketicilerin kalplerini ve zihinlerini fethetmeye çalışmaktadırlar (Torlak vd., 2016, s. 227-232). Her ürünün hitap ettiği potansiyel bir hedef kitle vardır. Pazarlama stratejisi gereği moda ve reklam endüstrisi tarafından beğeniler önceden tespit ve tasnif edilirler. Daha sonra tüketiciler bu beğeni kategorilerinden birinin içine yerleştirilerek tercihte bulunmaya zorlanırlar. Tüketici mağazaya girdiğinde farkında olsun veya olmasın hangi ürünü nereden alacağı bilinçaltına önceden kodlanmıştır. Böylece aynı tüketim evreni içerisinde (alışveriş merkezlerinde) toplanan tüketicilerin birbirlerine değmeden kendilerini sembolik farklılıklar üzerinden ifade ettikleri bir simülasyon ortamı yaratılmaktadır.

Hemen hemen bütün alışveriş merkezlerinde ayn markalar/mağazalar yer aldığından tüketici nereye gitse aynı manzarayla karşılaşmaktadır. Tüketim algısı ve tüketici bilinci bunlar tarafından şekillendirildiğinden bunun dışında bir gerçekliğin var olabileceğine dair, bunları aşan bir fikir ya da üst akıl üretilmesi pek de mümkün görünmemektedir. Tüketiciye düşen görev, üretimin birliğine ayak uydurmaktır. Üreticiler hem üretmiş oldukları ürünlere hem de içerisinde bizzat yer aldıkları üretim sistemlerine yabancılaştıklarından ötürü bilinçli bir ayırt edebilme arayışı içerisinde olmaksızın şeylerin mantığının çeşitlendirdiği ürünleri üretirler. Fakat üretim sisteminin felsefesi ve mantığı hakkında pek bir fikirleri yoktur. Çünkü üretim uzamı onların iradesinden bağımsız olarak işleyen, farklı malların 
üretilmelerini sağlayacak şekilde tasarlanmıştır (Bourdieu, 2016, s. 196). Bu sistemin içerisinde yer alan hemen hemen bütün tüketiciler çok özel bir nedeni olmadıkça üretim düzeninin felsefesini yapacak düzeyde teorik birikime sahip değildir. Geleneksel toplumda din, ahlak, gelenek vb. normlar bireyi topluma uymaya zorlarken üretim çağıyla birlikte bu anlayış irtifa kaybetmeye başlamıştır. Tüketim çağında toplum, bireye ayak uydurmaya çalışmaktadır. Birey bir yandan gereksinimlerden önce gelirken diğer yandan da gereksinimlere ayak uydurmak yerine onları kendine uydurmaya çalışmaktadır (Baudrillard, 2014, s. 206).

Kapitalist sistem, ayrım gözetmeksizin yaşlısından çocuğuna, erkeğinden kadınına hemen herkesi hem bireysel hem de sinıfsal olarak potansiyel tüketici olarak gördügünden üretim aşamasında bunların beğenilerini dikkate alır. Fakat beğeniler tıpkı alışkanlıklar gibi bizim doğuştan, kalıtımsal olarak getirdiğimiz özellikler değildir. Bourdieu, beğeninin nesneleşen ve bedenleşen, nesnel olarak uyumlu iki hikâyenin karşılaşması sonucu oluştuğunu belirtir. Beğeni, belirli bir kişi olarak sanatçının yapmış olduğu seçimler sonucu oluşan nesneleştirilmiş beğeni ile tüketicinin beğenisi arasındaki karşılaşmanın ürünüdürler. Beğeniler bir kez oluşturulduktan sonra geriye her beğeniye uygun ürünlerin üretilmesi ve müşterilerin kendi beğenilerine uygun nesneleri nasıl bulduklarını anlamak kalmaktadır (2016, s. 193-194). İnsanların özelliklerinin ve sahip olduklarının sosyolojisini yapmak onların beğenilerini anlamayı zorunlu kılmaktadır. $\mathrm{Bu}$, sunulan ürünlerin hangi koşullarda ortaya çıtığıyla tüketicilerin hangi koşullarda üretildiğini bilmeyi gerektirmektedir (Bourdieu, 2016, s. 196). Bu ilişki/ler ağının deşifre edilmesi beğeninin arkasında yatan bakış açısının ortaya çıkarılmasını mümkün hale getirmektedir.

\section{Alışveriş ve Eğlencenin Birleştirilmesi}

1970 ve 1980 yılları arasında alışveriş merkezleri iki yeni mekânsal form geliştirmişlerdir. Zincir mağazalar arasında indirim rekabetinin artması daha büyük zincir mağazaların (örneğin ABD'deki Wall-Mart, Avrupa'daki Auchan ve diğer zincirlerden) oluşmasına esin kaynağı olmuştur. Böylece daha düşük fiyatlarla daha geniş bir mal grubunu müşterilere sunan birlikler ortaya çıkmıştır. Süper ve hiper marketler, büyük depolar 
ve bunların bağlı olduğu güçlü merkezler bunları ayakta tutmuştur. Rekabetin artması kâr marjlarını düşürdügünden 1980'li yıllardan sonra işletme sahipleri ve stratejistler müşterileri alışveriş merkezlerinde daha uzun süre tutacak yeni arayışlar içine girmişlerdir. Bu arayışların bir sonucu olarak yeni inşa edilen daha büyük alışveriş merkezlerinde; tema parklardan sinema salonlarına kadar pek çok eğlence unsuru aynı çatı altında bir araya getirilmiştir (Zukin, 1998, s. 830). Alışverişin eğlenceyle birleştirilerek bir anlamda şölen ve festivale dönüştürülmesi alışveriş merkezleri arasında rekabeti ortadan kaldırmamış aksine yeni bir rekabete yol açmıştır. Günümüzde alışveriş merkezleri arasında karlılık, ciro, ziyaretçi sayısı, vb. alanlarda büyük bir rekabet vardır.

"Bu mekânlardaki tüketim pratikleri gerçekte boş zaman aktiviteleri ile iç içe geçmiştir. Tatil için ayrılan bütçenin büyük bir kısmı alışverişe gitmektedir. Bazıları ise, bunu daha uç bir noktaya taşımakta ve alışverişin tatilin kendisi haline geldiğini ileri sürmektedirler. Özellikle de Kanada'daki West Edmonton Alışveriş Merkezine, Niagara Şelaleleri'nden çok daha fazla paket tur düzenlenmektedir. Bu tüketim merkezlerinde, gerçek ürünlerin tüketilmesi yanında buraların "görsel olarak tüketilmesi" (Urry) gerçeğiyle de karşılaşıyoruz ve "gündelik hayatın estetikleştirilmesi"ne (Featherstone) dair kanıtların da toplandığı çoklu bir göstergeler dünyası buluyoruz. Büyülü ve renkli bu tüketim deneyimlerine ilişkin örnekler, kültürel deneyimin metalaştığını ve önemli ölçüde homojenleştiğini de ortaya koyar. Böylelikle belirli metalar küresel bir yaygınlık halesine" kavuşurlar (Tomlinson, 2004, s. 122).

Bugünkü tüketim ritüelleri bize, tüketimin sadece alışverişten ibaret olmadığını göstermektedir. Alışveriş merkezlerine gidenler alışverişin yanında yeme-içme, seyretme, etrafı dolaşma, vitrinlere göz gezdirme, ayrıca bakış'a dayalı hazcı algılamalar içine giriyorlar. Alışverişe, eğlence eşlik etmekte, restoranlar, pastaneler, kafeler, sinema salonları, yürüyüş parkurları, oyun parkları, çocuklara yönelik aktiviteler vb. yan etkinlik mekânları ile alışveriş çoklu bir yaşamsal kültüre kaynaklık etmekte, alışveriş merkezleri, pek çok şeyin iç içe geçtiği, birbiri üzerinden anlam kazandığı çoklu bir etkinliğe dönüşüyor. Dolayısıyla, tüketim bir ihtiyaç giderme etkinliği değil, bir keyif, hoşluk, hazcı, yerin hakkını vermek/tadını çıkarmak işidir. Tüketimcilik, ihtiyaç gidermekle sınırlı bir aktivite olmanın ötesinde sosyal, kültürel ve tarihsel bir bağlamla yakın- 
dan ilişkilidir. Bu durum, tüketimcilik etrafında yeni bir kimliklenme sürecinin boy attığı, filiz verdiği hatta bireyin tüketim mekanlarındaki görünürlüğü ve gösterdiği performans, onun statü, prestij, güç, popülarite, sinufsal konum, aidiyet grubu vs. gibi toplumdaki yerini tayinde kullanışlı bir gösterge haline gelmektedir (Bocock ve Thompson, 1992).

Adorno daha 1940'lı yıllarda eğlendirerek tükettirmekten ya da daha doğrusu tüketimin eğlence amaciyla sömürülmesinden ve tükettirmek için eğlencenin yem olarak kullanılmasından bahsetmektedir. Ona göre "kültür endüstrisinin getirdiği asıl yenilik, kültürün uzlaşılmaz /uzlaşmaz iki öğesi olan sanat ve eğlenceyi amaç kavramına yani tek bir yanlış formüle, kültür endüstrisinin bütünselliğine tabi kılmış olmasıdır. $\mathrm{Bu}$ formül yinelemeye dayanır" (Adorno, 2011, s. 67). Bu anlamda alışveriş merkezleri alışverişin yanı sıra sosyalleşme, eğlenme, dinlenme ve yemek olanakların bir arada sunan yeni bir toplumsallık modeli sunmaktadırlar. Fakat bu yeni toplumsallik geleneksel toplumlarda olduğu gibi dini veya ahlaki değerlere dayanmamaktadır. Aksine ticari kültüre ve ona ait kolektif belleğe dayanmaktadır (Zukin, 1998, s. 834). Bu mekânlarda, tüketim ile eğlence birbirinin içine geçmiş ve bu yönüyle tüketimin kendisi bir boş zaman geçirme olarak algılanır olmuştur. Bu noktada Amerika'nın en büyük alışveriş merkezlerinden biri olan "Mall of America" nın logosu bile çok şey söylemektedir: "Bu logoda alışveriş ve eğlence iç içedir. Burada asıl vurgulanmak istenen alışverişin eğlenceli bir şey olduğu, hatta eğlencenin ta kendisi olduğudur. Artık alışveriş eğlencedir. Logonun çağrışımı bir karnaval, lunapark havasındadır. Canlı renkler, eğlenen insanlar, uçuşan konfetiler ve renkli hediye paketleri logoya hakimdir. Tıpkı lunaparkların eğlenmek için gidilen özel, sinırlı yerler olması gibi, "Mall of America" da bir eğlence ve tüketim dünyası olma iddiasındadır." (Yırtıc1, 2005, s. 107-108). Bu iddia eğlence üzerinden temellendirilmektedir. Alışveriş merkezleri mekân içerisinde geçirilen zamanı maksimize etmek için tüketicilerin ilgisini çekmeye yönelik olarak pek çok eğlence çeşidi aynı/tek çatı altında bir arada sunulmaktadır.

Modern anlamda tüketim sadece ihtiyaç ve arzuların karşılanmasına dayanmamakta aksine modern tüketim eğlencenin bir parçası, uzantısı durumundadır. Tüketimin kendisi boş vakitlerin değerlendirildiği bir eğlenceye dönüşmüştür. Bu dönüşümde tüketim araçlarının ve özellikle 
de alışveriş merkezlerinin büyük rolü vardır. Bu tür mekânlar hiçbir zaman kendilerini sadece ihtiyaçların karşılandığı yerler olarak sunmazlar. Her zaman bir dizi eğlence imkânı da içerirler. İnsanların bugün büyük alışveriş merkezlerinde tükettikleri sadece ürünler ve hizmetler değildir. Bu tür merkezler sinema, yemek, çeşitli oyunlar gibi eğlence imkânlarının da tüketilmesini sağlamaktadırlar. Böylelikle gerçek tüketimle boş zamanın değerlendirme aracı olan eğlence tüketimi birbirine karışmıştır (Yırtıc1, 2005, s. 107). Kapitalizm koşullarında eğlence, çalışmanın doğal bir uzantısıdır. Kapitalizm, mekanikleşmiş emek süreciyle yeniden başa çıkabilmek için eğlenceyi bir sağaltma aracı olarak kullanmaktadır. Eğlence metalarının üretimi üzerinden boş zamanı olan insanların mutlu olma şekilleri belirli kalıplara dökülmektedir. Aslında burada sunulan içerik emek süreçlerinin soluk bir kopyasından başka bir şey değildirler. Zihinlere kazınmış normlaştırılmış işlemler kendi kendilerine devir daim eden rutinlerden başka bir şey değildir. Fabrika ya da bürolardaki emek süreçlerinden kaçan insanlar boş zamanlarını buna göre ayarlamaktadırlar (Adorno, 2011, s. 68-69).

$\mathrm{Bu}$ tür mekânlar sadece tüketicinin taleplerini tatmin etmeye yönelmekle kalmayıp, tıpkı reklamcılık gibi, insanlara daha önce "ihtiyaç duyduklarını" farkında bile olmadıkları mal ve hizmetleri tükettirmeye yönelmişlerdir. İnsanlar bu mekânlara girdikten sonra artık sadece mekânı deneyimlemeye değil, bunun yanında onlar için hazırlanmış olan pek çok mal ve hizmetleri tüketmeye yönlendirilmektedirler. Dahası buralar tüketicilerin daha fazla zaman geçirmesini ve daha fazla şey satın almasını sağlayacak şekilde tasarlanmıştır. Mesela; alışveriş merkezleri, tematik parklar ve kumarhaneler tüketicilerin buralarda ne kadar zaman harcadıklarının farkına varamamaları için zaman algısını da kapsayacak şekilde inşa edilmişlerdir (Ritzer, 2012, s. 6).

Küresel moda ve trendlere bağlı olarak alışveriş merkezleri bünyelerinde bulundurdukları mal ve hizmetlerle kentli kalabalıkların ilgisini üzerinde toplamaya devam etmektedirler. Özellikle, modern binaları, ziyaretçileri cezbedecek şekilde tasarlanmış "vitrinleri, sürekli çalan hafif batı müziği, sürekli serinlik sağlayan iklimlendirme düzeni ve en nihayet içinde barındırdığı sinema ve çeşitli yemek yerleriyle kentli insanların hafta sonları hoşça vakit" geçirmeleri için ideal bir seçenek haline gelmişlerdir (Bali, 2013, s. 132). Bu bağlamda AVM'ler, bir yandan tü- 
ketimci kapitalizmin gücünü ve sürekliliğini sağlamaya hizmet ederken öte yandan alışveriş ile eğlencenin içiçe geçtiği yeni bir kentli yaşam alanı/kültürü doğmuş olmaktadır.

Bundan başka, alışveriş merkezleri aynı zamanda, tüketimi bir eğlenceye ve şölene dönüştürmek suretiyle insanların enerjilerini topluma zarar vermeden boşaltmalarına olanak sağlamaktadır. Eğlence ve şölenler gündelik hayatın hengâmesinden bir nebze olsun kaçış imkânı sağlasalar da aslında üretimden sağlanan tasarruf tüketime kanalize edilerek sermayenin tekrar üretime dönmesi hedeflenmektedir. Sermayenin devir hızını arttırmak için insanlar iş dışındaki zamanlarının (leisure) çoğunu alışveriş merkezlerinde geçirmeye zorlanmakta ve hatta dahası insanlar adeta arkalarından buralara doğru itilmektedirler. Hoşumuza gitsin ya da gitmesin hayatımız tüketime ve tüketmeye olanak sağlayan araçlar arasında dolaşmakla geçmektedir.

\section{Kültürel Metalaşma ve Gündelik Hayatın Büyülenmesi}

Baudrillard, tüketim merkezlerinde, gündelik yaşamı tümüyle düzenleyen ve homojenleştiren tüketiciliğin büyüsü altında olduğumuza dikkatleri çeker. "Her şey soyut bir mutluluğun, yarı saydamlığına havale edilmiştir. Zorunlu iş, boş zaman, doğa ve kültür aktivitelerinin hepsi birbirine karışarak klimalı ve kapalı mekânda sonsuz bir alışverişe dönüşmüştür. Barber, bu noktada kültürün bütünüyle metalaştırma ilkesi etrafında dolayımlandığı görüşündedir. $\mathrm{O}$ bunu McDünya kavramı ile ifade eder ve her şeyi içine alan küresel kültürün bir sureti olarak görür. McDünya, alışveriş merkezlerini, multipleks sinemaları, konulu parkları, spor sahalarını, fast food zincirlerini ve hızla genişleyen alışveriş ağlarıyla televizyonu, kârını büyütme yolunda ilerlerken insanları dönüştüren tek ve büyük bir işletme içinde birleştirir" (Tomlinson, 2004, s. 123).

Ritzer ve Liska'ya göre, Kanada'daki West Edmonton Alışveriş Merkezi kültürel metalaşmanın en tipik örneğini oluşturmaktadır. Burada normal bir alışveriş merkezi ile lunapark birleştirilmiştir. Ritzer ve Liska, bunu "McDisneyleştirme" olarak nitelendirirler. John Urry ise, "hedonizmin, oyunculuğun ve derinliksiz tüketiciliğin" bu "en son tapınağını" şu şekilde betimler: "(...) Bir mil uzunluğundaki alışveriş merkezinin içinde 800 mağaza, dört tane mini denizaltısı, bir İspanyol 
kalyonunun reproduksiyonu ve yunusları olan bir hektardan daha geniş bir yapay göl, on sekiz delikli mini golf sahası, kırk restoran, dört hektarlık su parkı, bir XIX. yüzyıl taklidi Paris Bulvarı (kuşkusuz Haussman'ın kemikleri sızlayacaktır) gece kulüplerinin olduğu bir New Orleans sokağ1 ve hatta müşterilerine Hollywood, Roma ve Polonez gibi çeşitli tarzlarda odalar sunan bir otel de bulunmaktadır" (Tomlinson, 2004, s. 122; Aytaç, 2006, s. 39).

Baudrillard (1997), AVM'lerin bu çok yönlü, çok işlevli yapılarına ilişkin olarak, buraları bir tür kaleydoskop'a benzetmekte, her şeyi içine alabilecek bu merkezleri aynı zamanda bir meta panayırı olarak görmektedir. Baudrillard, aslında meta panayırı olarak nitelendirdiği bu yerlerin kullanıcılarına sunduğu küçük bir kent yaşantısı simülasyonu olduğunun da altını çizer. Alışveriş merkezleri, barındırdığı yapay ağaçlar, şelaleli havuzlar, telefon klübeleri, oturma bankları, çeşitli süs bitkileri, meydan saatleri vs. itibariyle neredeyse küçük birer kenti andırırlar. Her şey ayrıntılı şekilde hesaplanmış, koridorlar boyunca yürünen, kentlerin sokaklarını andıran, etrafı dükkânlarla dolu alışveriş aksları, kullanıcıları kentlerdeki benzerlerini andıran meydanlara çıkartır. Buralarda, etrafta dolaşırken banklarda suni bitki ve ağaçlara bakarak dinlenen insanlar, havuzun kenarında oynayan çocuklara kadar her şey kent yaşamında deneyimlenen görüntülerdir. Bundan başka alışveriş merkezleri, Oyun parkları, atlıkarınca, buz pateni pisti gibi eğlence ögeleri, panoramik asansörler, yürüyen merdivenler, kemerler, kubbeler, köprüler gibi mimari unsurların biraraya geldiği gerçeküstü mekânlar haline dönüşmüşlerdir.

Ritzer (2000), bu mekânları bir tür tüketim katedrallari olarak niteler. Bir bakıma bu mekânlar yarı dinsel yarı büyülü bir nitelik taşırlar. Kutsal arınma ve haz sağlayıcı özellikleri olduğu gibi, gündelik yaşamı renklendirici, büyüleyici, bunun üzerinden fantastik bir yaşam dünyası inşa edici bir nitelik de taşırlar. Bir başka deyişle, bu mekânlar kutsal bir mekâna girildiğinde hissedilen duyguya eş bir duygu sağanağı altına bizi sokar.

Ritzer, katedrallere benzettiği alışveriş merkezlerini, bir nevi hac gibi kutsal ve büyülü bir arınma duygusuyla ziyaret ettiğimizi vurgular. Buna misal olarak Alberta, Kanada'daki West Edmonton Mall, Minneapolis, Minnesota'daki Mall of America'yı vermektedir. Son yıllarda inşa 
edilen en büyük alışveriş merkezi, Los Angels dişında 200 mağazası ve 30 salonlu sinema kompleksiyle 500 bin metrekare büyüklügüündeki Ontario Mills'dir. Artık son zamanlarda alışveriş merkezleri Batı dışındaki üçüncü ülkelere de yayılarak yaşamın her alanını adeta dönüştürmektedir. Alı̧̧veriş merkezleri, artık, Las Vegas kumarhaneleri, yolcu gemileri, havalimanları, tren istasyonları ve kolej kampüslerine kadar yayılmış durumdadırlar. Hatta o kadar çok her yerde hazır ve nazırdırlar ki, Amerika, dünyanın en büyük alışveriş merkezi olarak da nitelendirilebilir (2000, s. 33-34; Aytaç, 2006, s. 39 ).

Alışveriş merkezleri ile dini kurumlar (katedraller) arasındaki ilişki sadece metaforik düzeyde değildir, aksine, alışveriş merkezleri bazı sembolik ve sosyal işlevleri itibariyle kiliselerin ve diğer ibadet mekanlarının karşıladığı işleve yakın bir fonksiyon ifa etmektedirler. Ira Gilbert Zepp (1997)'in bu ilişkiyi “The New Religious Image of Urban America" adlı eserinde detaylı bir şekilde ortaya koyar. Zepp, 1980'de on beş farklı ülkede 40 'dan fazla alışveriş merkezi üzerinde yaptığı araştırmada, yeni tüketim katedrallerinde dini sembolizm ve ritüel tutumların baskınlığına işaret eder. Alışveriş merkezleri ile dini kurumlar arasındaki ilişki metaforik olmanın ötesinde, bazı sembolik ve sosyal işlevleri açısından dini kurumların karşıladığı işleve benzer bir takım manevi tatmin olanakları sağladığını ifade eder (Vincenzo, 2018, s. 60). AVM'ler ne kadar büyük ve gösterişli ise, manevi tatmin telakkisi de o kadar görkemli ve "azizleri" de o kadar çok ve kalabalık olacaktır. Bundan dolayıdır ki, AVM'ler gerçekliğin bütün tonlarını hayatın her yönüne yayacak şekilde büyüyor, genişliyor. Özellikle hafta sonları neredeyse hiç sektirilmeden bu mekânlarda geçiriliyor, dini merasimlerin işlevsel muadilleri buralarda ifa ediliyor, böylelikle varoluşun tümüyle bu mekânlarda ikame edilebileceği duygusu yaratılmış oluyor. Dahası, bu mekânlarda geçirilen zaman, gerçek anlamda "hayat" olarak telakki edilip, kitlesel yığılmalar için operasyonel bir ideolojik altyapı hazırlanmış oluyor.

Alışveriş merkezleri, yapısı ve taşıdığı imge repertuarı itibariyle sembolik anlamlar ve referanslar içermekte; birçok alışveriş merkezi, kendilerini basit bir meta pazarından "çok daha fazlası" olarak tanımlamakta. Zepp'e (1997) göre, bu "çok daha fazlası" bilinçli olsun ya da olmasın dini bir referanstır, hatta belki de metafizik bir referans ve 
alışveriş merkezlerinin gerçek gizemini sağlayan ana espri de belki buradan kaynaklanmaktadır.

AVM'ler çoğunlukla kalabalıkları kendine çekebilmek için büyüleyici bir mimari tarzda tasarlanmakta, birbirinden cazip ürün ve kampanyalarla tüketicileri kendilerine çektikleri oranda büyüleyiciliklerini arttırmaktadırlar. Başarılı büyü ortamlarının tüm dünyada şubeleri açılmasıyla aynı büyü çok geniş bir yelpazede yeniden üretilebilmektedir. Büyünün sistematize edilerek bir mekândan diğerine kolay bir şekilde transfer edilebilmesi (Ritzer, 2000, s. 28) aynı zamanda yazılı kuralları olmayan yeni bir yaşam pratiğinin de hayata geçirilmesine karşılık gelmektedir. Tüketiciler marka, kalite, güven ve satış sonrası hizmetler üzerinden buralarda sunulan mal ve hizmetlerle aralarında bir ünsiyet kurmaktadırlar.

Weber geleneksel toplumdan modern topluma geçişi açıklarken büyünün akılcılaşma sonucu bozulmasına işaret ederken bugün aslında tam tersi bir durum yaşanmaktadır. Alışveriş merkezlerinin ileri düzeyde akılcılaşarak büyüleyiciliklerinin artması, bir zamanlar aklın öncülügünde büyünün pençesinden kurtularak özgürleşen insanları tekrar yeniden aklın öncülügünde büyüleyici tarzda tasarlanan mekânlara çağrılarak adeta özgürlükleri ellerinden alınmaktadır. Ritzer (2000, s. 48) dinlerin çekiciliklerini arttırmak için mabet inşasında alışveriş merkezlerini taklit etmeye başladıklarına işaret etmektedir. Mesela; Batı'da “dev kiliseler çelik ve camdan inşa edilmektedir. Kiliselerin alışveriş merkezlerinin otoparkları gibi dönümlerce park yerleri vardır... "En şıklarında aerobik salonları, bowling alanları, danışma merkezleri ve sunuşun MTV ile rekabet ettiği multimedia İncil sınıfları vardır. Pazar sabahı büyük ekranlarda, herkesin görüp takip edebilmesi için pop tarzı ilahiler ve Eski Ahit'ten sureler belirir."

Modern yaşam simge ve semboller etrafında örgütlendiğinden alı̧̧veriş merkezleri çekiciliklerini arttırmak için yeni büyüler üretmek zorundadırlar. Çoğu zaman bunun için kültürel simgeler kullanılmaktadır. Özellikle son yıllarda "küresel işletmeler girdikleri yabancı ülkelerde tutunabilmek için ürün ve markalarını yerel değerler ve kültürel simgelerle özdeşleştirme stratejisi gütmektedirler. Özellikle de yabancı ürünlere yönelik direnci kırmak ve yabancı karşıtlığını engellemek için ürünlerini yerel değerler, gelenekler ve alışkanlıkların bir 
parçası haline getirme çabası içerisine girmişlerdir. Bu bağlamda en güzel örnek, son yillarda Coca Cola ve Pepsi'nin Türkiye'de Ramazan ayındaki reklamlarında kolayı bir kültürel değer olan Ramazan Pidesi'yle özdeşleştirme girişimidir" (Torlak vd., 2017, s. 244)Yeni büyüler üretemeyen marka veya tüketicileri kendilerine çekmekte yeterince başarılı olamayanlar bulundukları mahallin, yerel markası, mağazası veya marketi konumuna düşmektedirler.

\section{Sonuç}

Alışveriş merkezleri, modern kentlerin kitlesel yığılmaya sahne olan önemli karargâhlarından biri durumundadırlar. Tüm dünyada küresel bir hızla çoğalan bu yerler, sadece alışveriş yapmaya değil, aksine, gündelik yaşamın pek çok pratiğini bir araya getiren bütünleşik bir dünyayı temsil ederler. İnsanlar buralarda hem ihtiyaçlarını gidermekte hem de eğlenme, dinlenme, seyretme, vakit geçirme, oyun oynama, statü/prestij ve kimlik edinme gibi çoklu tatmin elde ederler. Bu mekânlar, böylelikle, gündelik yaşamın sıkıcılı̆̆ını, rutinliğini aşmaya hizmet etmiş olurlar. Ancak her rutini aşma uğraşısı gibi alışveriş merkezleri müdavimleri de bir süre sonra yeni bir rutinin kontrolüne girdiklerini hissederler. Doğal olarak bu onları daha keskin ve sıra dışı seçenekler aramaya iter.

Modern yaşantı gerçekte dur durak bilmeksizin yenilik, değişiklik, sıra dişılık, heyecan ve haz avcılığının çemberinde kendini tekrarlayıp durur. Alışveriş merkezleri, tüketimin cazibesi üzerine kurulu, tüketimci siyasayı hayata geçirme yolunda oluşturulan en etkin araç durumundadır. Alışveriş merkezlerinin tüketimin yanısıra, yeme içme, gezme, eğlenme, hoşça vakit geçirme vb. imkânlar sunacak şekilde düzenlenmesiyle birlikte, bu mekânlar gündelik hayatın merkezi kurumları haline gelmişlerdir. Böylelikle her türden etkinlik, mal ve hizmetleri tüketmeye hizmet edecek şekilde dizayn edilerek, tüketimin çoklu arzu ve isteklere karşılık gelecek şekilde karşılanmasının yolu açılmış olmakta. Bu mekânlarda tüketiciler, zamanın nasıl geçtiğini farketmeyecekleri bir mimari tasarım üzerinden maniple edilmekte, güvenli bir ortam oluşturularak tüketicilerin buralarda uzun zaman ve ailece kalmaları garanti altına alınmakta, yeme/içme ve eğlenme ihtiyaçlarına karşlık vermek suretiyle onların gündelik yaşamlarının bir çekim 
merkezi haline gelmesi sağlanmış olmaktadır. Buralar aynı zamanda, gözetim ve denetim stratejilerine uygun şekilde her türden yapıp etmelerin kaydedildiği, ancak bunun güvenlik saikiyle kotarılmaya çalışıldığı bir gözetleme üssünü andırmaktadırlar.

Alışveriş merkezleri sadece tüketim ürünlerinin değil, sosyal ve kültürel deneyimlerin de tüketildiği bir mekân olarak öne çıkarlar. Aşırı akılcılaştırılmış üretimin sürekliliğinin sağlanabilmesi tüketimciliğin teşviki ve reklam, moda, trend, festival vs. yoluyla kitlenin alışveriş merkezlerine yığışması sağlanmaktadır. Bu merkezler, kentli kalabalıkların kamusal deneyimler yaşama, kent hayatına katılma, kentli atraksiyonlar sergileme vs. açısından da oldukça işlevseldirler. Çoklu işlevler gördüğ̈̈nden, geniş yığınları kendi bünyesinde toparlayabilmekte, onlara mekân, kültür, cinsiyet ve sınıf üzerinden ayrıştırıcı kimlikler atfedebilmektedir. Bu yüzden, kentli yurttaşlar, AVM'ler üzerinden kentli yaşam kültürünün bir parçası, onun atfettiği kimliklerin bir göstereni haline gelmektedirler. 


\title{
EXTENDED ABSTRACT
}

\section{Symbolic Spaces of Multiple Experience: Shopping Centers}

\author{
* \\ Ömer Aytaç - Musa Öztürk \\ Firat University - Yildırım Beyazıt University
}

In today's world shopping malls are one of the central institutions of the capitalism. Day by day they attract more and more people by providing different experiences to their regular visitors and with their multifunctions. Malls do attract, not only dwellers of the city in which they located, also people living adjacent area of the city and even in metropolitan and border cities people from neighbouring states.

Both in developed and developing countries the shopping malls represents almost a common cultural and life experience. As various goods and services are being presented together in these shopping centers, they are able to gather masses from all walks of the society, regardless of their age, gender, social class, education and vocational category. Thus they could produce common experiences and cultural forms. In other words, multi functionality of these malls enable them to supply differentiated identities via culture, space, gender and class. So they make people feel themselves special. They carry out these functions by their reach repertoire of activities. For instance; in today's cities young people, children, women, men, families and elders can find specially designed places to consume activities peculiar/dedicated to them under the roof of the malls. In this context shopping centres represents a new type of living space of our age. Shopping malls inherently involve symbolic references. They do consider themselves something more than being "simply a market". They present themselves as the address of the complex and to that extent "multi" experiences that provides whole functions covering all aspects of daily life. They force us to consume more, to show a higher performance in consumption by providing goods and services in a wide range. Thus we spend more money and most of our time at there. On 
that sense shopping malls shows characteristics of a coloured, lightened, appealing hyperspace. The fast flow of time and space, free circulation of goods and services, swift flow of people and capital render shopping malls one of the central institutions of the global world.

Till recent times people were browsing/walking a lot of places/shops on their own to meet their needs for goods and services. This situation today turned to meet the needs, together with a lot of people in a collective manner by buying the same things from the same place. This daily life practice became probably the most important central characteristics of the urban life or modern daily life. This consumerist practice, experienced in all cities and metropolises of the world and produced such a conclusion that peoples of poor and underdeveloped countries begun to consume the same goods and services with people from developed countries with the same appetite and desire. Everybody eats/drinks/wears same things, use same stuff/furniture, watch the same movies and do almost all of these in the spaces designed with a special logic. This situation shows that a global socio-cultural transformation took place. With other words the melting of all regional and spatial differences, on the base of spatial sameness, under the roof of shopping centres and replacement of them on a different context of relation and socialization shows that malls have different faces and functions other than the visible ones.

After the entrance of shopping malls to our daily life, our consumption types changed a lot. In a sense consumption gained a carnivalesque appearance. The meaning attributed to the consumption changed fundamentally by the intertwining of the consumption and entertainment. From now on consumption no more means, activities to meet the basic needs; on the contrary it means a quest for entertainment, satisfaction, pleasure, desire for change and even happiness. Therefore malls are no more institutions where we buy goods and services. As a result of this change; the way of life, culture and identity they offer, generate an important ground for sociological inquiries.

Alongside shopping, people also consume the space, meet/encounter the other people and pursue social representation. Being in a mall also is an expression of individuality. With this aspect, shopping centers are important platforms of socialization. People spend a lot of time at there. 
They meet their needs such as meeting with friends, eating/drinking, watching around, glancing each other and entertainment. Especially at weekends this places becomes one of the most vivid/crowded social environments of urban daily life culture where masses mostly prefers (or influx). People, in these places, as agents of a new consumption oriented life style, engage into multi experiences, imagined sociality and new identity building processes. New cultural patterns and identities constructed through space, further atomizes fragmented nature of modern daily life. Within this framework, samples of new culture and life style such as spatial communities, imagined sociality, individual and identity representations, conspicuous experiences, consumerist leisure activities etc. frequently come into the forefront.

This work focuses on the misleading nature of handling shopping centers just as bases of consumption. Work, to the contrary of this misleading approach, constructs these centres as composite spaces producing a life/culture pattern via multi functions which socially, culturally and symbolically supplement daily life. From this perspective, it can be seen that shopping malls have a quite operational function for the sustainability of the neoliberal economic and political order. As a summary this work claims that, shopping malls are on the focus of urban and metropolitan life, they are able to construct a rhetoric of publicity exclusive to them, they do consecration of consumption and manipulation of consumer in a sophisticated manner and create an effective background for commodification and fascination of daily life by combining shopping and entertainment.

\section{Kaynakça/References}

Adorno, T. W. (2011). Kültür endüstrisi. (Çev. N. Ülner, M. Tüzel ve E. Gen), İstanbul: İletişim Yayınları.

Aytaç, Ö. (2017). Kent mekânlarının sosyo-kültürel coğrafyası. K. Alver (Der.), Kent sosyolojisi içinde (ss. 251-279), Ed. Köksal Alver, Konya: Çizgi Kitabevi Yayınları.

Aytaç, Ö. (2006). Tüketimcilik ve metalaşma kıskacında boş zaman. Kocaeli Üniversitesi Sosyal Bilimler Dergisi, 11(1), 27-53 
Bali, R. A. (2013). Tarz-ı hayat'tan life style'a. İstanbul: İletişim Yayınları.

Banerjee, T. (2001). The future of public space: beyond invented streets and reinvented places. Journal of the American Planning Association, Wntr, 67, .9-24.

Baudrillard, J. (1997). Tüketim toplumu. (Çev. H. Deliçaylı, F. Keskin), İstanbul: Ayrıntı Yayınları

Baudrillard, J. (2009). Gösterge ekonomi politiği hakkında bir eleştiri. (Çev. O. Adanır ve A. Bilgin), İstanbul: Boğaziçi Üniversitesi Yayınevi.

Baudrillard, J. (2014). Nesneler sistemi. (Çev. O. Adanır), İstanbul: Boğaziçi Üniversitesi Yayınevi.

Bocock, R. ve Kenneth T. (Ed.) (1992). Social and cultural forms of modernity. Oxford, Blackwell Publishing Ltd.

Bourdieu, P. (2016). Ayrım, beğgni yargısının toplumsal eleştirisi. (Çev. D. F. Şannan ve A. G. Berkkurt), Ankara: Heretik Yayınları.

Castells, M. (1997). Kent, sınıf ve iktidar. (Çev. A. Erendil), Ankara: Bilim ve Sanat Yayınları.

Chaney, D. (1999), Yaşam tarzları. (Çev. İ. Kutluk), Ankara: Dost Kitabevi.

Douglas, M. (2017), Saflık ve tehlike. (Çev. E. Ayhan), İstanbul: Metis Yayınları.

Durakbaşa, A. ve Cindoğlu, D. (2003). Tezgâh üstü karşllaşmalartoplumsal cinsiyet ve alışveriş deneyimi. D. Kandiyoti ve A. Saktanber (Ed.), Kültür fragmanları (Türkiye'de gündelik hayat) içinde (ss. 84-100). İstanbul: Metis Yayınları.

Ertürk, H. ve Karakurt Tosun, E. (2009). Küreselleşme sürecinde kentlerde mekânsal, sosyal ve kültürel değişim: bursa örneği. Uludağ Üniversitesi Sosyal Bilimler Enstitüsü Dergisi, 16, 37-52.

Friedman, T. (2006). Dünya düzdür. (Çev. L. Cinemre), İstanbul: Boyner Yayınları.

Harvey, D. (2012a). Sermayenin mekânları. (Çev. B. Kıcır, D. Koç, K. Tanrıyar ve S. Yüksel), İstanbul: Sel Yayınları.

Harvey, D. (2012b). Sermaye muamması. (Çev. S. Savran), İstanbul: Sel Yayınları.

Jameson, F. (2011). Postmodernizm ya da geç kapitalizmin kültürel mantığı. (Çev. N. Plümer ve A. Gölcü), Ankara: Nirengi Kitap

Lefebvre, H. (2016). Mekânın üretimi. (Çev. I. Ergüden), İstanbul: Sel Yayınları. 
Müğan Akıncı, G. (2013). Gençler ve alışveriş merkezleri (avm'ler): avm kullanım tercihleri hakkında bir alan çalışması. Megaron, 8(2), 8796.

Ritzer, G. (2000). Büyüsü bozulmuş dünyayı büyülemek. (Çev. Ş. S. Kaya), İstanbul: Ayrıntı Yayınları.

Ritzer, G. (2011a). Küresel dünya. (Çev. M. Pekdemir), İstanbul: Ayrıntı Yayınları.

Ritzer, G. (2011b). Toplumun mcdonaldlaştırılması. (Çev. Ş. S. Kaya), İstanbul: Ayrıntı Yayınları.

Ritzer, G. (2012). "Hyperconsumption" and "hyperdebt": a "hypercritical" analysis. Ralph Brubaker, Robert M. Lawless and Charles J. Tab (Ed.), A Debtor World, inside (pp. 60-80). England: Oxford University Press.

Tomlinson, J. (2004). Küreselleşme ve kültür. (Çev. A. Eker), İstanbul: Ayrintı Yayınları

Topal, A. (2003). Global kapitalizmde sermaye birikimi için yeni mekânsal ölçekler: dünya kentleri/global kentler. Çă̆daş Yerel Yönetimler, 12(2), 41-61.

Torlak, Ö., Remzi A. ve Özdemir, Ş. (2017). Pazarlama ilkeleri ve yönetimi. İstanbul: Beta Yayınları.

Urry, J. (1999). Mekânları tüketmek. (Çev. R. G. Öğdül), İstanbul: Ayrıntı Yayınları.

Vincenzo, G. (2018). Tüketim katedrali. (Çev. İ. Aydın), Nihayet Dergi, Sayı 40, Nisan

Vural, T. ve Yücel, A. (2006). Çağımızın yeni kamusal mekânları olarak alışveriş merkezlerine eleştirel bir bakış. İTÜdergisi, mimarlık, planlama, tasarm, 5(2), 97-106

Yırtıc1, H. (2005). Çă̆daş kapitalizmin mekânsal örgütlenmesi. İstanbul: İstanbul Bilgi Üniversitesi Yayınları.

Zepp, I. G. (1997). The new religious image of urban america, the shopping mall as ceremonial center. University press of Colorado

Zukin, S. (1998). Urban lifestyles: diversity and standardisation in spaces of consumption. Urban Studies, 35(5), 825-839. 


\section{Kaynakça Bilgisi / Citation Information}

Aytaç, Ö. ve Öztürk, M. (2018). Çoklu deneyimin sembolik mekânları: Alışveriş merkezleri. OPUS-Uluslararası Toplum Araştırmaları Dergisi, 9(16), 2033-2066. DOI: 10.26466/opus.471825 